настроениям граждан, что в конечном итоге отрицательно сказывается на экономическом состоянии государства. Отсутствие возможности реализовать свои способности может породить внутренний протест у пассионарных личностей, которые могут направить свои действия на разрушение, а не на созидание. Именно подобные неблагоприятные ситуации породили диктаторов и привели к революциям.

Современная Россия, как представляется, четко и ясно обозначила консервативный путь развития, однако наш консерватизм еще далек от совершенства. Много говориться о коррупции в органах власти, высоком уровне преступности, что, безусловно, мешает проявлению свободы граждан и вызывает необходимость борьбы с данными явлениями.

Исходя из вышесказанного, необходимо сказать, что свобода для консерватизма должна выражаться в возможности беспрепятственно реализовывать гражданами своих способностей и в то же время не причинять вред правам и свободам других граждан, а также действующим в интересах населения государственным и общественным институтам.

1. Бредихин А.Л., Руденко Д.А. Политико-правовые взгляды западников в России в XIX веке: взаимосвязь политической идеологии и правопонимания. - М.: Литрес, 2019.

2. Монтескье Ш.Л. О духе законов. М.: Мысль, 1999.

3. Ниязов Х. Философия свободы и право на информацию// Актуальные проблемы гуманитарных и естественных наук . 2017. № 2-2.

4. Русаков А.Г. Взгляды русских философов на правовой нигилизм/ В сборнике: НАУКА И ОБРАЗОВАНИЕ: ОПЫТ, ПРОБЛЕМЫ, ПЕРСПЕКТИВЫ РАЗВИТИЯ. материалЫ ХІV международной научно-практической конференции. Ответственные за выпуск: А.А. Кондрашев, Е.И. Сорокатая. 2015.

\title{
Цой С.В. \\ Влияние США на процессы взаимодействия государств Корейского полуострова
}

ФГБОУ ВО «Астраханский государственный университет» (Россия, Астрахань)

doi: $10.18411 / 1 j-08-2021-73$

\section{Аннотация}

В статье рассматривается влияние, которое в современном глобализирующемся мире оказывают на КНДР и РК Соединенные Штаты Америки. Указывается, что их изначальное участие в межкорейском расколе, а также продолжающееся сотрудничество с Южной Кореей и противоречивая политика по отношению к Северной обуславливают сохранение этого раскола и служат важным препятствием для сближения государств Корейского полуострова.

Ключевые слова: государства Корейского полуострова, США, раскол, взаимодействие, влияние.

\section{Abstract}

The article deals with the influence that is taking place in the modern globalizing world on the North Korea and the South Korea of the United States. It is indicated that from the main participation in the inter-Korean split, as well as the ongoing cooperation with South Korea and the contradictory policy towards the North, they cause the preservation of this split and an important obstacle to the rapprochement of the states of the Korean Peninsula.

Keywords: states of the Korean Peninsula, USA, split, interaction, influence.

Глобализация современного мира приводит ко многим значимым тенденциям. Первой из них является взаимозависимость субъектов международной системы. 
Принимаемые современными государствами решения по вопросам внутренней и внешней политики в большинстве своем обусловлены общим состоянием международной системы и влияющих на нее факторов. В подобных условиях приобретает значение еще одна глобализационная тенденция - доминирование в мировых взаимоотношениях ряда субъектов, как правило, определяющихся как мировые державы.

Одной из таких держав в современном мире являются США. Их влияние в международной системе определяется широким спектром экономических, коммуникационных, военно-политических и пр. ресурсов, использование которых направлено на обеспечение интересов этого государства, расширение и поддержание его влияния. В этом контексте анализ воздействия США на государства Корейского полуострова представляет собой важную исследовательскую задачу, так как арсенал ресурсов этих государств также весьма широк. Он начинается ядерной программой КНДР и заканчивается коммуникационными технологиями РК. Объединение этих ресурсов могло бы стать основой для значительного возрастания роли каждого из государств Корейского полуострова на международной арене, что может восприниматься США как потенциальная угроза и служить основой для проводимой ими актуальной «корейской» политики.

Соответственно, рассмотрение влияние США на процессы взаимодействия государств Корейского полуострова является целью данной статьи.

Ее задачи:

1. Определить основные составляющие воздействия США на Республику Корея.

2. Обозначить главные тенденции их взаимодействия с КНДР и охарактеризовать их влияние на межкорейское взаимодействие.

Объектом статьи выступает влияние США на современные международные процессы, а предметом - их воздействие на взаимодействие Северной и Южной Кореей.

Характеризуя влияние США на современную Республику Корея отметим фундаментальность этого влияния. Находясь у истоков раскола корейского государства, Соединенные Штаты изначально получили возможность определять политические процессы Южной Кореи. Это в первую очередь обусловило политикорежимные и экономические различия, которые по сей день являются для корейских государств фундаментальными.

Однако, ситуация зависимости не означала отсутствия между США и РК формальной договорной базы взаимодействия. Одним из первых документов, обусловивших такое важное направление американской политики как военнополитическое, стал Договор о взаимной обороне [5]. Его подписание состоялось в 1953 г., и обеспечивало США право «размещать сухопутные, воздушные и морские войска на территории Республики Корея и вблизи нее» [5]. Важно, что и на сегодняшний день согласно этому документу в Южной Корее находятся американские войска, общей численностью 28,5 тысяч человек [6]. Это, очевидно, служит подтверждением сохраняющегося в РК американского влияния.

Еще одним немаловажным аспектом воздействия США на РК является военнополитический альянс между этими государствами, включающий еще одного важного регионального субъекта, Японию. Истоки этого трехстороннего альянса относятся в 1960-м годам, когда усилиями Соединенных Штатов были налажены взаимоотношения между Южной Кореей и Японией (колонией которой долгое время было корейское государство).

С указанного периода безопасность РК была объявлена США проблемой не только Соединенных Шатов, но и Японии, как ближайшего регионального союзника. На сегодняшний день деятельность альянса выражается в возрастании «масштабов и 
частоты военных учений с отработкой оперативно-тактических задач уничтожения ракетно-ядерных арсеналов КНДР, проникновения вглубь ее территории и ликвидации северокорейского руководства» [3, с. 285]. Другими словами, поддержка США предполагает противопоставление РК и КНДР, что служит фактором, осложняющим их взаимодействие.

Еще одним, подтверждающим это аспектом американской политики в отношении РК являются вопросы экономики и санкций. Экономическое сотрудничество между этими государствами также имеет продолжительную историю. На сегодняшний день главным регулирующим его документом является Соглашение о свободной торговле, подписанное в 2007 г. [7]. В данный момент Соединенные Штаты являются для Южной Кореи одним из главных торговых партнеров. Объем их двусторонней торговли составляет порядка 150-ти млд. долл., из которых большая половина приходится на экспорт товаров РК в США [4]. Еще одним важным направлением экономического сотрудничества являются прямые инвестиции, поступающие как из Соединенных Штатов в Южную Корею, так и в обратном порядке.

В целом как характеризует экономические взаимоотношения этих государств Фархетдинова Э.Т.: «...позиция Южной Кореи среди торговых партнеров США была относительно последовательной в течение последних двух десятилетий. На данный момент экспортная экономика Южной Кореи и конкуренция в сбыте некоторых продуктов привели к некоторым трениям в торговле. Однако, несмотря на это оба государства осознают и уже не могут разорвать тесную связь своих экономических связей, и тем самым идут на некоторые уступки и принимают новые соглашения» [2, с. 144].

Таким образом, в отношениях США и Республики Корея можно отмечать достаточную последовательность и ориентацию Соединенных Штатов не только на продвижение своих интересов в рамках этого государства, но и на противопоставление его «северному соседу». В области экономики это нашло свое отражение в рамках режима международных санкций. В соответствии с ним Южная Корея не может реализовать экономические, а значит и наиболее важные для КНДР, направления сотрудничества с этим государством. Главным в связи с этим становится менее контролируемое извне социальное направление диалога, которое способствует, однако не обеспечивает, значительной динамики межкорейского взаимодействия.

Непосредственная политика США в отношении КНДР носит весьма противоречивый характер, что также осложняет возможности диалога между Северной Кореей и Южной Кореей, так как последняя является стратегическим союзником американского государства.

В наибольшей степени эта непоследовательность нашла свое выражение в период предыдущего президента США Д. Трампа. Она находилась в интервале между обещаниями «огня и ярости» в 2017-м году и встречей лидеров двух государств в демилитаризированной зоне в 2019-м г. Провальный саммит, прошедший в октябре 2019 г. стал символичной точкой политики администрации Д. Трампа [1]. Не удивительным является тот факт, что пришедший ему на смену Дж. Байден заявил о пересмотре проводившей ранее политики в отношении КНДР.

В это понятие пересмотра вошло допущение о возможности предоставления Северной Корее гуманитарной помощи. Этот тезис является важным, так как проводящаяся северокорейским руководством ядерная программа привела значительному ограничению для страны этого важного ресурса. Однако большинство экспертов заявляют о том, что у действующей американской администрации нет видения новых форматов взаимодействия с КНДР [1]. Основная стратегия представляется в форме возрождения принципа терпения и выжидания.

В целом характеризуя влияние США на КНДР и РК можно согласиться с А.И. Шарафетдиновой в том, что «поддержание контролируемого очага напряженности на 
Корейском полуострове выгодно Соединенным Штатам с точки зрения сохранения глобального военного доминирования» [3, с. 286]. На сегодняшний день Соединенные Штаты оказывают непосредственное влияние на Южную Корею, и путем системы международного взаимодействия стремятся обеспечить свой контроль над Северной. Для обеспечения своего приоритетного влияния в Северо-Восточной Азии им необходимо наличие одного, как РК, союзного государства или двух, но разобщенных и не способных объединить свои ресурсы и выстроить единую стратегию международной политики. В этом контексте можно говорить о том, что влияние США на взаимодействие государств Корейского полуострова будет реализовываться в рамках выбранных стратегий поддержания их разобщенности и ослабления КНДР.

$$
* * *
$$

1. «Демократический» подход: зачем США вновь подняли вопрос денуклеаризации Корейского полуострова URL: https://russian.rt.com/world/article/831612-ssha-denuklearizaciya-kndr-baiden

2. Фархетдинова Э.Т. Двусторонние отношения Республики Корея и США в экономической сфере на современном этапе. Казанский вестник молодых ученых. - 2019. - Том 3. - № 1 (9). - С. 135-146.

3. Шарафетдинова А.И. Военно-политические аспекты политики США на корейском полуострове после 1945 года // КНДР и РК - 70 лет. - М.: ИДВ РАН, 2018. - С.277-290.

4. Korean Statistical Information Service. URL: http://stat.kita.net/stat/istat/OtherMain.screen?ctrGb=U

5. Mutual Defense Treaty between the United States and the Republic of Korea. URL: www.avalon.low.yale.edu/20th_century/kor001.asp

6. S. Korean, U.S. troops begin joint field training. URL: http://english.yonhapnews.co.kr/news/2018/04/01/0200000000AEN20180401000600315.html

7. United States-Korea Free Trade Agreement // World Intellectual Property Organization. URL: http://www.wipo.int/edocs/trtdocs/en/kr-us/trt_kr_us.pdf 